DOI: $10.37190 /$ epe 170209

\title{
ASSESSMENT OF IRON OXIDE AND LOCAL CEMENT CLAY AS POTENTIAL FLUORIDE ADSORBENTS
}

\begin{abstract}
Health problem from fluoride contaminated water is more acute in rural and small urban communities. Defluoridation of low contaminated water by inexpensive adsorbents is a substantial practice worldwide. In the study, low-cost sorbents have been investigated as replacements for current costly methods of removing the excess fluoride from water below the certain concentration. The adsorption capacity of iron oxide and cement clay in fluoride removal was investigated by the batch method. The equilibrium time was attained in $3 \mathrm{~h}$ and $2 \mathrm{~h}$ for iron oxide and cement clay, respectively. Optimum adsorbent dosage was found to be $5 \mathrm{~g} / \mathrm{dm}^{3}$. Initial fluoride concentrations for the adsorption studies were 1.24 and $12.2 \mathrm{mg} / \mathrm{dm}^{3}$. Fluoride adsorption isotherm fitted well the Freundlich isotherm with the coefficient of determination $>0.99$ for both adsorbents. The fluoride adsorption capacity of iron oxide was found higher than that of cement clay due to the high surface area and charge of iron oxide. However both substances can reduce $\mathrm{F}^{-}$contamination below the acceptable limits of $1.5 \mathrm{mg} / \mathrm{dm}^{3}$ for less contaminated water.
\end{abstract}

\section{INTRODUCTION}

Fluorine is an essential microelement for animals and human whose intake in the proper extent protects teeth against carries especially in childhood, but high fluoride water has detrimental effects on bones and teeth (dental caries) and long-term exposure at higher concentrations can lead to tooth and bone poisoning [1]. Health and Human Services' (HHS) recommendation of $0.7 \mathrm{mg} \mathrm{F}^{-} / \mathrm{dm}^{3}$ of water replaces the current recommended range of 0.7 to $1.2 \mathrm{mg} / \mathrm{dm}^{3}$. This updated recommendation is based on recent Environmental Protection Agency (EPA) and HHS scientific assessments to balance the benefits of preventing tooth decay while limiting any unwanted health effects. These scientific assessments will also guide EPA in making a determination of whether to

${ }^{1}$ Faculty of Engineering, Department of Environmental Engineering, Harran University, Osmanbey Campuse 63190, Şanlıurfa, Turkey, corresponding author A. D. Atasoy, e-mail: adilekatasoy@hotmail.com 
lower the maximum amount of fluoride allowed in drinking water, which is set to prevent adverse health effects [2]. Especially the incidence of health problems arising from excessive exposure to fluoride is higher in human living in rural areas and providing the drinking water from ground waters.

There are several defluoridation techniques, which can be categorized into four main categories namely precipitation, membrane processes and ion exchange /adsorption onto various adsorbents [3, 4]. Adsorption is an effective purification and economical technique for fluoride removal from drinking water compared to other technologies [5]. It is the most suitable process for drinking water treatment as the fluoride concentration in ground water is very low $\left(5-40 \mathrm{mg} / \mathrm{dm}^{3}\right)$ [6]. Ground water is the major source of water in these rural areas, while a replacement by uncontaminated drinking water sources is not manageable. Various adsorbents have been tested for fluoride removal, including alumina [7], activated carbon [8], bentonite [9], clay [10-12] and red mud [13].

The presence of high metal oxides especially iron in some materials may make them suitable for water defluoridation [14]. Numerous researchers have used iron oxide as an adsorbent to treat heavy metals and anions from wastewater [15]. Iron-based materials have also been extensively studied for fluoride removal as iron shows better affinity towards fluoride. Among various natural materials examined for defluoridation of water, various types of clays have been explored to a great extent [16]. In this study, low-cost sorbents have been investigated as replacements for current costly methods of removing the excess fluoride from water below the acceptable limit of $1.5 \mathrm{mg} / \mathrm{dm}^{3}$. The aim of the present study was to assess the adsorption potential of iron oxide and cement clay for fluoride removal from water. Defluoridation studies were conducted in batch adsorption mode under various experimental conditions, such as contact time, initial fluoride concentrations and adsorbent dosage. The data from the experiments were fitted with isotherm models to compare the adsorption capacities of two sorbents.

\section{MATERIALS AND METHODS}

The characteristics of adsorbents. Cement clay and commercial iron oxide were used as two adsorbents in the present study. Cement clay was local material procured from Yarimtepe village of Sanliurfa, Turkey. Analytical grade iron oxide was obtained from a national company. Chemical compositions of materials are presented in Table 1. $\mathrm{SiO}_{2}$ is the most distinct component in the cement clay and this was followed by $\mathrm{CaO}$ and $\mathrm{Al}_{2} \mathrm{O}_{3}$ phases. Chemical composition of clay exhibited as: 30.51 wt. \% of $\mathrm{SiO}_{2}$, 23.65 wt. $\%$ of $\mathrm{CaO}$, and $7.64 \%$ wt. $\%$ of $\mathrm{Al}_{2} \mathrm{O}_{3}$. Iron oxide consists of mostly $\mathrm{Fe}_{2} \mathrm{O}_{3}$ (84.40 wt. \%). 
Table 1

Chemical composition of adsorbents [wt. \%]

\begin{tabular}{|l|c|c|}
\hline \multicolumn{1}{|c|}{ Compound } & Cement clay & Iron oxide \\
\hline $\mathrm{SiO}_{2}$ & 30.506 & 0.338 \\
\hline $\mathrm{Al}_{2} \mathrm{O}_{3}$ & 7.641 & 0.077 \\
\hline $\mathrm{Fe}_{2} \mathrm{O}_{3}$ & 5.603 & 84.397 \\
\hline $\mathrm{MgO}$ & 6.285 & 0.03 \\
\hline $\mathrm{CaO}$ & 23.654 & 0.042 \\
\hline $\mathrm{Na}_{2} \mathrm{O}$ & 0.069 & 0.266 \\
\hline $\mathrm{K}_{2} \mathrm{O}$ & 2.019 & - \\
\hline $\mathrm{TiO}_{2}$ & 0.651 & 0.014 \\
\hline $\mathrm{P}_{2} \mathrm{O}_{5}$ & 0.133 & 0.011 \\
\hline $\mathrm{MnO}_{2} \mathrm{O}$ & 0.058 & 0.138 \\
\hline $\mathrm{Cr}_{2} \mathrm{O}_{3}$ & 0.052 & 0.027 \\
\hline Loss of ignition & 23.330 & 14.660 \\
\hline Total & 100 & 100 \\
\hline
\end{tabular}

Adsorption studies. Adsorption isotherms of fluoride on clay and iron oxide were obtained by the batch equilibrium method [17]. Adsorption equilibrium time, optimum adsorbent dosage and adsorption isotherms were determined by adsorption tests at natural $\mathrm{pH}$ (5.7 for iron oxide and 7.9 for cement clay) at room temperature. Initial $\mathrm{F}^{-}$concentrations were $14 \mathrm{mg} / \mathrm{dm}^{3}$ and $5 \mathrm{mg} / \mathrm{dm}^{3}$ for the adsorption equilibrium time tests and the optimum adsorbent dosage tests, respectively. Stock solution $\left(100 \mathrm{mg} / \mathrm{dm}^{3}\right)$ was prepared by dissolving $0.221 \mathrm{~g}$ of anhydrous $\mathrm{NaF}$ (Merck) in $1 \mathrm{dm}^{3}$ of deionized water. This was further diluted to get the desired concentrations $(1.24,2.45,3.95,4.89,7.49$, $9.67,12.2 \mathrm{mg} / \mathrm{dm}^{3}$ ) for practical use.

Tests were conducted in duplicate in $50 \mathrm{~cm}^{3}$ polypropylene test tubes. Test solutions of $14 \mathrm{mg} \mathrm{F}^{-} / \mathrm{dm}^{3}$ and $5 \mathrm{mg} \mathrm{F}^{-} / \mathrm{dm}^{3}$ were prepared from fresh stock solution. Samples $\left(40 \mathrm{~cm}^{3}\right)$ were shaken on a reciprocating shaker $(150 \mathrm{rpm})$ for $1,2,3,4,5,11,24 \mathrm{~h}$ and then supernatant was filtered through $0.45 \mu \mathrm{m}$ syringe filters and analyzed for the residual $\mathrm{F}^{-}$. Optimum conditions were selected for further studies. Contact time was regarded $3 \mathrm{~h}$ and $2 \mathrm{~h}$ for iron oxide and cement clay, respectively, in the equilibrium studies. Applied adsorbent dosages were; $2.5,5,10,15,30 \mathrm{mg} / \mathrm{dm}^{3}$ in the study. Adsorption models were determined using Langmuir and Freundlich isotherms. Fluoride analyses were performed by a Hach mark Fluoride Meter by TISAB (total-ionic strength adjustment buffer) method. This method can be used for measuring the concentration of $1-10 \mathrm{mg} \mathrm{F}^{-} / \mathrm{dm}^{3}$ total solubilized fluoride in drinking waters. Total solubilized fluoride is determined potentiometrically using a fluoride ion-selective electrode [18]. All the experiments were executed with controls-with only $\mathrm{F}^{-}$in tube (no adsorbents) and blanks with the same amount of adsorbent in tube (without $\mathrm{F}^{-}$). All reported results constituted the mean of duplicate measurements. 
Data analysis. Adsorption data were analysed using linearized form of the Langmuir (Eq. (1)) and Freundlich isotherms (Eq. (2)):

$$
\begin{gathered}
\frac{C_{e}}{C_{s}}=\frac{1}{Q_{0} b}+\frac{C_{e}}{Q_{0}} \\
\log C_{s}=\log K_{f}+\frac{1}{n_{f}} \log C_{e}
\end{gathered}
$$

where $b$ is the Langmuir constant $\left(\mathrm{dm}^{3} / \mathrm{mg}\right)$ and $Q_{0}$ is the maximum amount of adsorbate $(\mathrm{mg} / \mathrm{g})$ that can be adsorbed. In the plot $C_{e} / C_{s}$ versus $C_{e}$, the slope is $1 / Q_{0}$ and the intercept is $1 /\left(Q_{0} b\right) . K_{\mathrm{f}}\left(\mathrm{dm}^{3} / \mathrm{g}\right)$ and $1 / n_{f}$ (non-dimensional) are the empirical Freundlich constants. By plotting $\log C_{s}$ (amount of adsorbed fluorides to adsorbent mass, $\mathrm{mg} / \mathrm{g}$ ) versus $\log C_{e}$ (amount of fluoride in solution at equilibrium state, $\mathrm{mg} / \mathrm{dm}^{3}$ ), $1 / n_{f}$ is calculated as the slope of the curve and the intercept is equal to $\log K_{f}[19]$.

\section{RESULTS AND DISCUSSION}

\subsection{EQUILIBRIUM TIME}

The adsorption exhibited a rapid increase within $1 \mathrm{~h}$. In the present case, $\mathrm{F}^{-}$adsorption in iron oxide and cement clay leveled off within $3 \mathrm{~h}$ and $2 \mathrm{~h}$, respectively (Fig. 1).

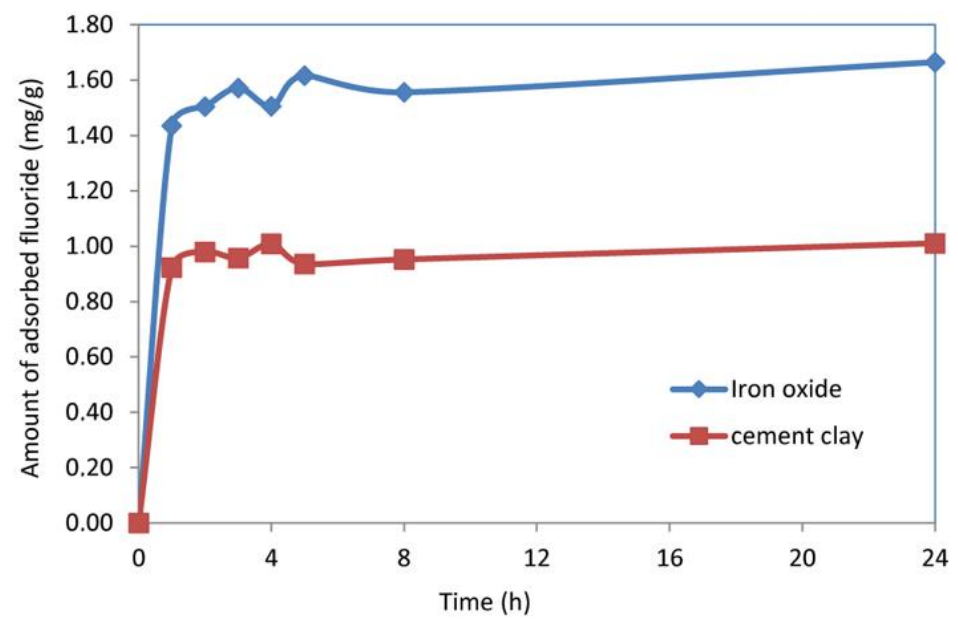

Fig. 1. Effect of contact time on the fluoride adsorption:

adsorbent dosage $-5 \mathrm{~g} / \mathrm{dm}^{3}$, initial $\mathrm{F}^{-}$concentration $-14 \mathrm{mg} / \mathrm{dm}^{3}, \mathrm{pH}-5.7$ for iron oxide and 7.9 for cement clay, $T-25^{\circ} \mathrm{C}$ and shaking rate $-150 \mathrm{rpm}$ ) 
The rapid $\mathrm{F}^{-}$sorption was followed by a slow sorption within $24 \mathrm{~h}$ in the iron oxide and cement clay. As pointed out by Tang et al. [20], Gao et al. [21] and Sundaram et al. [22], there is likely an initial quick sorption, a surface phenomenon, followed by slow migration and diffusion of the $\mathrm{F}^{-}$ions into the adsorbent interlayers and surfaces. It was assumed that the equilibrium time is that at which curves appear nearly asymptotic to the time axis. Because the changes in solution concentration were rather small after reaching equilibrium, the equilibrium time was used in the remaining adsorption studies. Atasoy et al. [23] specified the similar phase for $\mathrm{F}^{-}$adsorption in the bauxite. It was mentioned that the changes in solution concentration were quite small after reaching equilibrium.

\subsection{OPTIMUM ADSORBENT DOSAGE}

The influence of adsorbent dose on fluoride removal at a fixed initial fluoride concentration of $5 \mathrm{mg} / \mathrm{dm}^{3}$ is shown in Fig. 2.

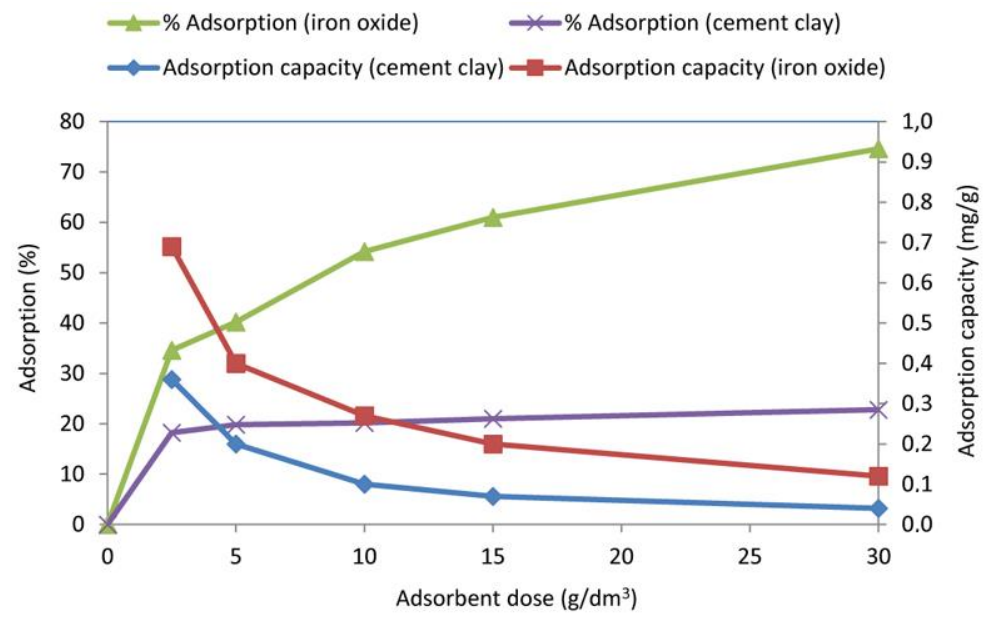

Fig. 2. Effect of adsorbent dose on the fluoride adsorption:

initial $\mathrm{F}^{-}$concentration $-5 \mathrm{mg} / \mathrm{dm}^{3}, \mathrm{pH}-5.7$ for iron oxide and 7.9 for cement clay, $T-25^{\circ} \mathrm{C}$ and shaking rate $-150 \mathrm{rpm}$ )

The percentage of $\mathrm{F}^{-}$adsorbed increased with the increase in adsorbent dosage and it was obviously due to the enhanced active sites with an increase in the amount of adsorbent $[22,24]$. The maximum adsorption capacity was found to be 0.36 and $0.69 \mathrm{mg} / \mathrm{g}$ for cement clay and iron oxide, respectively, at the minimum dose of adsorbent $\left(2.5 \mathrm{~g} / \mathrm{dm}^{3}\right)$. Higher adsorbent dose results in lower adsorption of fluoride by unit mass of adsorbents ( $\mathrm{mg} / \mathrm{g}$ ). Similar behavior has also been reported previously for other adsorbents [21, 25]. Percentage removal of fluoride increased from $35 \%$ to $75 \%$ and from $18 \%$ to $23 \%$ with 
an increase in iron oxide and cement clay dose from 2.5 to $30 \mathrm{~g} / \mathrm{dm}^{3}$, respectively. However, it was noticed that above a dosage of $5 \mathrm{~g} / \mathrm{dm}^{3}$ for cement clay, there was no significant change in the removal rate of fluoride. It was due to the: (i) overlapping of active sites at higher dosage, thus, reducing the net surface area and; (ii) non adsorbability of fluoride ions as a result of sorbent-sorbate interaction.

Continuous increase of iron oxide dose resulted in the increase of $\mathrm{F}$ adsorption. Any fixed value cannot be chosen from the graph in Fig. 2. Therefore, $5 \mathrm{~g} / \mathrm{dm}^{3}$ was also fixed as optimum adsorbent dosage and it was used as the further study. Higher doses are not economic for the removal costs.

\subsection{INITIAL CONCENTRATION EFFECT}

Effect of initial concentration on removal of fluoride was studied at various initial fluoride concentrations by keeping constant other parameters such as adsorbent dose $5 \mathrm{~g} / \mathrm{dm}^{3}$, temperature $25^{\circ} \mathrm{C}$, $\mathrm{pH}$ of cement clay 7.9 and $\mathrm{pH}$ of iron oxide 5.7 , shaking speed $150 \mathrm{rpm}$ and contact time $3 \mathrm{~h}$ for iron oxide and $2 \mathrm{~h}$ for cement clay. The effect of initial concentration on the removal of fluoride is shown in Fig. 3.

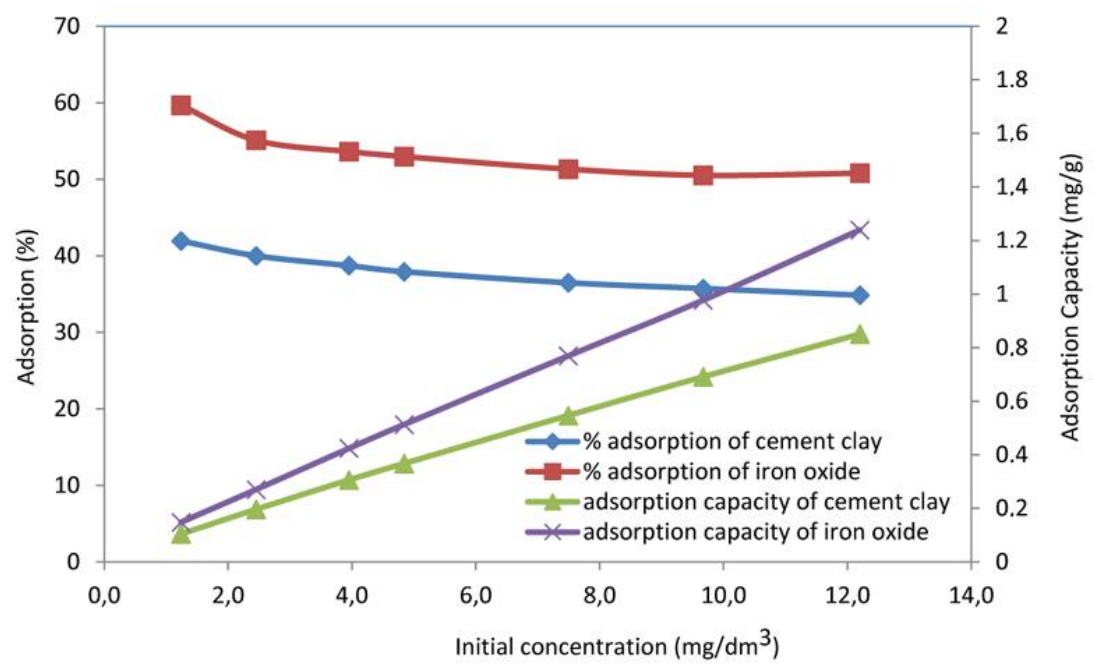

Fig. 3. Initial fluoride concentration effects on the fluoride adsorption:

adsorbent dosage $-5 \mathrm{~g} / \mathrm{dm}^{3}$, shaking (equilibrium) time $-3 \mathrm{~h}$ for iron oxide and $2 \mathrm{~h}$ for cement clay, $\mathrm{pH}-5.7$ for iron oxide and 7.9 for cement clay, $T-25^{\circ} \mathrm{C}$ and shaking rate $-150 \mathrm{rpm}$ )

It was observed that upon increasing initial concentration, fluoride adsorption capacity increased and this is due to the high amount of fluoride ions available for adsorption increasing with the increase in initial fluoride concentration and the number of fluoride ions available per active site. 


\subsection{ADSORPTION ISOTHERMS}

Values of the Langmuir and Freundlich adsorption constants are summarized in Table 2. The Langmuir equation yielded a poor fit to $\mathrm{F}^{-}$adsorption on iron oxide. The coefficient of determination for the Langmuir equation for $\mathrm{F}^{-}$adsorption was 0.77 and 0.95 for the iron oxide and cement clay, respectively. Fluoride adsorption isotherm fitted well with the Freundlich isotherm with a coefficient of determination $>0.99$ for both sorbents. The Freundlich model is empirical in nature which assumes the adsorption on a heterogeneous surface. Adsorption on the cement clay followed the Freundlich isotherm better than the Langmuir isotherm, as reported by Gao et al. [21] suggesting the similar fitting for the $\mathrm{F}^{-}$adsorption of nanosized hydroxyapatite.

Table 2

Freundlich and Langmuir isotherm constants for the fluoride adsorption on cement clay and iron oxide

\begin{tabular}{|c|l|c|c|}
\hline Isotherm & \multicolumn{1}{|c|}{ Constants } & Cement clay & Iron oxide \\
\hline \multirow{5}{*}{ Freundlich } & $K_{f}, \mathrm{dm}^{3} / \mathrm{g}$ & 0.140 & 0.257 \\
\cline { 2 - 4 } & $\log K_{f}$ & -0.855 & -0.590 \\
\cline { 2 - 4 } & $1 / n_{f}$ & 0.875 & 0.855 \\
\cline { 2 - 4 } & $n_{f}$, non-dimensional & 1.143 & 1.170 \\
\cline { 2 - 4 } & $R^{2}$ & $>0.99$ & $>0.99$ \\
\hline \multirow{5}{*}{ Langmuir } & $1 /\left(Q_{0} b\right)$ & 7.044 & 3.698 \\
\cline { 2 - 4 } & $1 / Q_{0}$ & 0.317 & 0.233 \\
\cline { 2 - 4 } & $b, \mathrm{dm}^{3} / \mathrm{mg}$ & 0.045 & 0.063 \\
\cline { 2 - 4 } & $Q_{0}, \mathrm{mg} / \mathrm{g}$ & 3.155 & 4.290 \\
\cline { 2 - 4 } & $R^{2}$ & 0.95 & 0.77 \\
\hline
\end{tabular}

According to the Giles classification, $\mathrm{F}^{-}$adsorption isotherm for both clay and iron oxide was the type $\mathrm{C}$, which is indicative of partitioning between the adsorbent surfaces and solution without any specific bonding (Fig. 4). The C type isotherm is indicative of a partitioning mechanism whereby adsorptive molecules are distributed or partitioned between the interfacial phase and the bulk solution phase without any specific bonding between the adsorbent and adsorbate.

The values of $1 / n_{f}$ for $\mathrm{F}^{-}$adsorption were about 0.9 and did not vary between the adsorbents studied (Table 2). The fact that $1 / n_{f}$ was smaller than unity implies that as the initial concentration of the system increases adsorption decreases [18]. Smaller value of $1 / n(<1)$ indicates a weaker bond (physical bonding) between adsorbate and adsorbent and also it indicates the heterogeneous adsorbent surface [14]. It is generally stated that values of $n$ in the range of 2-10,1-2 and $<1$ indicate, good, moderate and poor adsorption characteristics, respectively. 
The higher $\mathrm{F}^{-}$adsorption was found for iron oxide $\left(84.4 \% \mathrm{Fe}_{2} \mathrm{O}_{3}\right.$ content) with $K_{f}$ (Freundlich adsorption coefficient, $\mathrm{dm}^{3} / \mathrm{g}$ ) and $Q_{0}$ (Langmuir constant, $\mathrm{mg} / \mathrm{g}$ ) values of $0.257\left(\mathrm{dm}^{3} / \mathrm{g}\right)$ and $4.290(\mathrm{mg} / \mathrm{g})$, respectively. It's thought that the fluoride retention took place on the positively charged ends which bonded with iron atoms. Thus, adsorption phenomena occurred due to the attraction between the opposite poles and $\mathrm{F}^{-}$adsorbed on the positive sites of adsorbent. In the natural environment, fluoride is strongly adsorbed onto surfaces of many iron-containing minerals. Therefore, iron hydr(oxide) are natural sorbents for fluoride removal [20]. Iron oxide has a relatively high surface area and charge; Huang et al. [15] inferred that waste iron oxide was an efficient adsorbent for the removal of fluoride ions in an aqueous system.

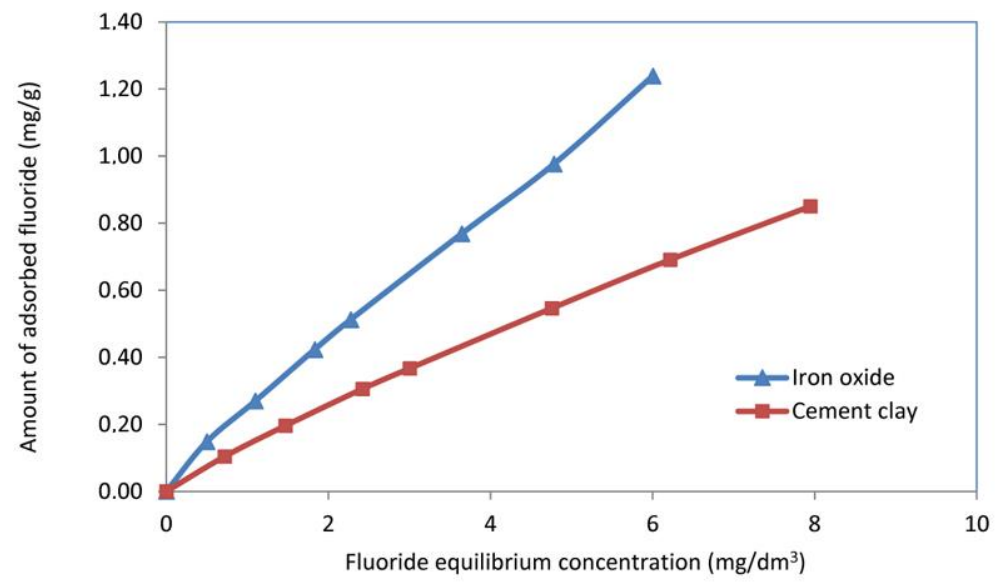

Fig. 4. Adsorption isotherms of iron oxide and cement clay

adsorbent dosage $-5 \mathrm{~g} / \mathrm{dm}^{3}$, shaking (equilibrium) time $-3 \mathrm{~h}$ for iron oxide and $2 \mathrm{~h}$ for cement clay, $\mathrm{pH}-5.7$ for iron oxide and 7.9 for cement clay, $T-25^{\circ} \mathrm{C}$ and shaking rate $-150 \mathrm{rpm}$ )

Poor $\mathrm{F}^{-}$adsorption was found on the cement clay. This fact principally exhibited the weaker bond (physical bonding) between $\mathrm{F}^{-}$ions and adsorbent [9] or easy desorption of $\mathrm{F}^{-}$from the positive sites. Poor adsorption capacity of raw clay is related to its negatively charged sites and consequently the weaker retention of $\mathrm{F}$ ions on the clay.

Low fluoride contamination $\left(\leq 2.5 \mathrm{mg} / \mathrm{dm}^{3}\right)$ can be reduced below the acceptable limits of $1.5 \mathrm{mg} / \mathrm{dm}^{3}$ by cement clay (with $40 \%$ adsorption). Iron oxide reduces $\mathrm{F}^{-}$concentration to the same limit from a little high level $\left(\leq 3.3 \mathrm{mg} / \mathrm{dm}^{3}\right)$ of contaminated water (with 54\% adsorption). Consequently, relatively low in cost, simple and environmental friendly adsorbents and adsorption method used in the present study is regarded appropriate for the endemic areas of the developing towns and takes care of the problem of other conventional methods $[3,5,10,23,24]$. 


\section{CONCLUSIONS}

The Freundlich equation provided a good fit to the isotherms for $\mathrm{F}^{-}$adsorption on both iron oxide and cement clay. Low fluoride adsorption was found on the cement clay. Negatively charged sites probably created an opposite effect on the $\mathrm{F}^{-}$adsorption. Adsorption of fluoride ions on iron oxide $\left(K_{f}=0.26\right)$ was higher than that of cement clay $\left(K_{f}=0.14\right)$ due to the high surface area and charge of iron oxide. Maximum $\mathrm{F}^{-}$adsorption $(75 \%)$ was found for $30 \mathrm{~g} / \mathrm{dm}^{3}$ of iron oxide dose and $5 \mathrm{mg} / \mathrm{dm}^{3}$ initial F $\mathrm{F}^{-}$concentration. However, $5 \mathrm{~g} / \mathrm{dm}^{3}$ was fixed as optimum adsorbent dosage because of the non-economic removal costs for the higher doses. Both iron oxide and cement clay can reduce the $\mathrm{F}^{-}$contamination below the acceptable limits of $1.5 \mathrm{mg} \mathrm{F}^{-} / \mathrm{dm}^{3}$ for the less contaminated water $\left(2.5 \mathrm{mg} \mathrm{F}^{-} / \mathrm{dm}^{3}\right.$ for cement clay or $3.3 \mathrm{mg} \mathrm{F}^{-} / \mathrm{dm}^{3}$ for iron oxide). Iron oxide and cement clay are low in cost, simple, environmental and efficient raw adsorbents to purify the low fluorine water. Modification of raw adsorbent perhaps will allow increase in its adsorption capacity. Future research will be focused on searching more efficient modified adsorbents for water defluoridation.

\section{ACKNOWLEDGMENT}

This study was funded by the Scientific and Technological Research Council of Turkey (TUBITAK project No. 110Y234) and the Scientific Research Projects Committee of Harran University (HÜBAK) under grant No. 2011-1167.

\section{REFERENCES}

[1] Ansari M., Kazemipour M., Dehghani M., Kazemipour M., The defluoridation of drinking water using multi-walled carbon nanotubes, J. Fluor. Chem., 2011, 132, 516.

[2] U.S. Department of Health \& Human Services, http://www.hhs.gov/

[3] Lunge S., BINIWALE R., LABHSETWAR N., RAYALU S.S., User perception study for performance evaluation of domestic defluoridation techniques for its application in rural areas, J. Hazard. Mat., 2011, $191,325$.

[4] FAN X., PARKER D.J., SMith M.D., Adsorption kinetics of fluoride on low cost materials, Water Res., 2003, 37, 4929.

[5] Ramdani A., Taleb S., Benghalem A., Ghaffour N., Removal of excess fluoride ions from Saharan brackish water by adsorption on natural materials, Desalination, 2010, 250, 408.

[6] Mandal S., Mayadevi S., Defluoridation of water using as-synthesized Zn/Al/Cl anionic clay adsorbent: Equilibrium and regeneration studies, J. Hazard. Mat. 2009, 167, 873.

[7] GHORAI S., PANT K.K., Equilibrium, kinetics and breakthrough studies for adsorption of fluoride on activated alumina, Sep. Purif. Technol., 2005, 4, 265.

[8] Ma Y., WANG S.G., FAN M., Gong W.X., GAO B.Y., Characteristics and defluoridation performance of granular activated carbons coated with manganese oxides, J. Hazard. Mat. 2009, 168, 1140.

[9] Thakre D., Rayalu S., Kawade R., Meshram S., Subrt J., Labhsetwar N., Magnesium incorporated bentonite clay for defluoridation of drinking water, J. Hazard. Mat., 2010, 180, 122.

[10] Atasoy A.D., ŞAHIN Ö.M., Adsorption of fluoride on the raw and modified cement clay, Clean, 2014, $42(4), 415$. 
[11] ZHUANG J.I., GUI-RUi E.Y., Effects of surface coatings on electrochemical properties and contaminant sorption of clay minerals, Chemosphere, 2002, 49, 619.

[12] Kau P.M.H., Sмith D.W., Binning P., Fluoride retention by kaolin clay, J. Contam. Hydrol., 1997, 28, 267.

[13] Cengeloglu Y., Kir E., Ersoz M., Removal of fluoride from aqueous solution by using red mud, Sep. Purif. Technol., 2002, 28, 81.

[14] Sujana M.G., Pradhan H.K., Anand S., Studies on sorption of some geomaterials for fluoride removal from aqueous solutions, J. Hazard. Mat., 2009, 161,120.

[15] HuAng Y.H., SHIH Y.J., CHANG C.C., Adsorption of fluoride by waste iron oxide: The effects of solution $\mathrm{pH}$, major coexisting anions, and adsorbent calcination temperature, J. Hazard. Mat., 2011, 186 (2-3), 1355 .

[16] Bhatnagar A., Kumar E., Sillanpaa M., Fluoride removal from water by adsorption. A review, Chem. Eng. J., 2011, 171 (3), 811.

[17] Atasoy A.D., Mermut A.R., Kumbur H., Ince F., Arslan H., Avci E.D., Sorption of alpha and beta hydrophobic endosulfan in a Vertisol from southeast region of Turkey, Chemosphere, 2009, 74,1450.

[18] Liu H., Deng S., Li Z., Yu G., HuAng J., Preparation of Al-Ce hybrid adsorbent and its application for defluoridation of drinking water, J. Hazard. Mat., 2010, 179, 424.

[19] Sparks D.L., Environmental soil chemistry, Academic Press, San Diego 1995.

[20] Tang Y., Guan X., Wang J., GaO N., Mcphail M.R., Chusuei C.C., Fluoride adsorption onto granular ferric hydroxide: Effects of ionic strength, $\mathrm{pH}$, surface loading, and major co-existing anions, J. Hazard. Mat., 2009, 171, 774.

[21] Gao S., Cui J., Wei Z., Study on the fluoride adsorption of various apatite materials in aqueous solution, J. Fluorine Chem., 2009,130, 1035.

[22] Sundaram C.S., Viswanathan N., MeEnakshi S., Defluoridation of water using magnesia/chitosan composite, J. Hazard. Mat., 2009, 163, 618.

[23] AtASOy A.D., YesilnaCAR M.I., ŞAHIN Ö.M., Removal of fluoride from contaminated ground water using raw and modified bauxite, Bull. Env. Cont. Toxicol., 2013, 91, 595.

[24] Wambu E.W., Onindo C.O., Ambusso W., MuthaKia G.K., Removal of Fluoride from Aqueous Solutions by Adsorption Using a Siliceous Mineral of a Kenyan Origin, Clean, 2013, 41 (4), 340.

[25] Agarwal M., Rai K., Shrivastas R., Dass S., Defluoridation of water using amended clay, J. Clean. Prod., 2003, 11, 439. 